\title{
Comparative assessment of evapotranspiration in Bhima sub-basin using spatial analysis for normal and ENSO years
}

\author{
DIGAMBAR S. LONDHE* and YASHWANT B. KATPATAL \\ Visvesvaraya National Institute of Technology, Nagpur, Maharashtra \\ *Corresponding author: digambarlondhe@students.vnit.ac.in
}

\begin{abstract}
Evapotranspiration (ET) estimation is important for hydrological modelling and water management for irrigation. The present study estimates the reference evapotranspiration using FAO Penman-Monteith (FAO P-M) method and SWAT hydrological model, and its spatial variation during ENSO events during 1996 to 2013. The spatial variation of crop coefficient and actual evapotranspiration $\left(E T_{a}\right)$ is also analyzed. The results from these methods are compared for various EI Niño-Southern Oscillation (ENSO) events and normal years. MODIS NDVI data was used to generate crop coefficients which were further used for generation of $\mathrm{ET}_{\mathrm{a}}$. The results show that the $\mathrm{ET}$, estimated using $\mathrm{FAO} P-\mathrm{M}$ is less during the pre-monsoon period than $\mathrm{ET}_{0}$ estimated using SWAT model. ET, values from FAO P-M show decreasing trends while those by SWAT show increasing trends. Also, ET, shows higher values during post monsoon period of EI Niño years as compared to La Niña and normal years.
\end{abstract}

Keywords: Evapotranspiration, SWAT, ENSO, NDVI

The available ground water and surface water resources are overexploited and reaching the limit of ecologic sustainability. Evapotranspiration is combination of two different processes; evaporation on the ground surface and transpiration in the plants and vegetation, leads to considerable loss of water resources (Thornthwaite and Mather, 1957). Accurate ET estimates are essential to improve the distribution of water resources, to categorize the time variations on irrigation needs, and to evaluate the influence of the use of the land and changes in the water balance (Shrestha and Shrestha, 2017).

Rainfall is the major source of water in India for agriculture (CWC and NRSC, 2014). Hence, reliable and consistent estimate of ET is necessary not only for environmental sustainability and biodiversity, but also in the context of agriculture. Estimation of ET is difficult particularly over complex terrains not easily approachable for measurements (Abiodun et al., 2018). To overcome this problem, various methods are adopted for the calculation of the reference evapotranspiration $\left(\mathrm{ET}_{0}\right)$ by using climatological data, such as maximum and minimum temperature, solar radiations, wind speed and relative humidity.

There are various methods and equations used to calculate the reference $\mathrm{ET}_{0}$ depending upon the availability of climatological data, such as Food and Agricultural Organization (FAO) Penman-Monteith equation (Penman,
1948; Monteith, 1965), Thornthwaite equation (Thornthwaite and Mather, 1957), Hargreaves equation (Hargreaves and Allen, 2003), Hamon equation (Hamon, 1961). FAO Penman-Monteith method is preferred as the standard and accurate method for daily $\mathrm{ET}_{0}$ estimation however, this method has stringent requirement of collecting correct quality climatological data from field. To overcome this limitation, in recent studies, remote sensing and GIS techniques are used for quantification of ET in more accurate and easy way. Crop coefficient $\left(\mathrm{K}_{\mathrm{C}}\right)$ is the factor which is used to calculate $\mathrm{ET}_{\mathrm{a}}$ with the help of $\mathrm{ET}_{0}$. Increase in $\mathrm{K}_{\mathrm{C}}$ caused by higher temperature results in decrease in soil water and decline in NDVI, while dense vegetation induces more ET and lowers the land surface temperature (Kumar et al., 2013).

In this study, FAO Penman-Monteith method and SWAT model (Arnold et al., 1994) were used for the ET estimation. Penman-Monteith method utilizes only meteorological parameters such as temperature, wind speed, solar radiation and humidity (Zotarelli et al.,2015) while SWAT utilizes weather parameters along with the soil data, land use land cover data and slope information. But, FAO P$\mathrm{M}$ method generates results for observation points where the meteorological data is collected while the SWAT method generates only one value of $\mathrm{ET}_{0}$ for whole watershed. $\mathrm{K}_{\mathrm{C}}$ values are generated throughout the watershed using the NDVI. Then $\mathrm{K}_{\mathrm{C}}$ values have been used for generation of $\mathrm{ET}_{\mathrm{a}}$. 
The major objectives of the study hence are to estimate the $\mathrm{ET}_{0}$ for Bhima sub-basin using Penman-Monteith method and SWAT hydrologic model; record spatial variation of $\mathrm{ET}_{0}$ for different phases of ENSO events; estimate spatial variation of $\mathrm{K}_{\mathrm{C}}$ and $\mathrm{ET}_{\mathrm{a}}$.

\section{MATERIALS AND METHODS}

\section{Study area}

The Bhima River is one of the major tributaries of the Krishna River.The study area lies between latitude $17.18 \mathrm{~N}$ to $19.24 \mathrm{~N}$ and longitude $73.20 \mathrm{E}$ to $76.15 \mathrm{E}$ (DRAFT report, Upper Bhima sub-basin). Location map of the study area is as shown in Fig.1. The major meteorological parameters used in the study are temperature, humidity, wind speed, and sunshine hours and solar radiations. It was observed that the minimum temperature observed was $5^{\circ} \mathrm{C}$ and maximum temperature was $46^{\circ} \mathrm{C}$ during 2002 to 2013 .

\section{Data description}

The map of the study area (Fig.1) has been generated from the Water Resources Information System (WRIS) of India. The Digital Elevation Model (DEM) of the study area is used for the watershed delineation in the ArcSWAT software. The Shuttle Radar Topography Mission (SRTM) DEM with $30 \mathrm{~m}$ spatial resolution is used for the analysis (Fig. 1) with highest elevation of $1472 \mathrm{~m}$ and lowest elevation of $160 \mathrm{~m}$ in the Eastern part of the basin.

The soil data with $10 \mathrm{~km}$ spatial resolution from SWAT database along with soil properties viz. particle size distribution, bulk density, organic carbon content and available water capacity were obtained using Reynolds et al. (1999) by Schuol and Abbaspour (2007). Land use map is an important input for SWAT Model. It affects the generation of run-off, soil water storage, water demand for irrigation, etc. Land use map is available on the SWAT dataset of India. The Western Ghat zone the west part of study area covered with thick forest, receives heavy rainfall (maximum of 4500 mmyear $^{-1}$ ), while the central part of the Upper Bhima receives the lowest rainfall less than 500 mmyear $^{-1}$ (Garg et al., 2012). SWAT requires daily data of precipitation, maximum and minimum temperature, solar radiation, wind speed and relative humidity. In this analysis, weather data from year 2000 to 2013 for 38 weather stations were used for the calculation of $\mathrm{ET}_{0}$.

This study includes analysis and comparison of ET losses in the atmosphere with the help of Penman-Monteith method and SWAT Hydrological model. There are many methods adopted for the estimation of $\mathrm{ET}_{0}$. In the SWAT Hydrological model, various datasets such as DEM, soil data, land use land cover data, weather data, etc. are required as input of the model. SWAT is the model interface with the ArcGIS software. The flow chart of the overall methodology has been shown in Fig. 2 .

\section{FAO Penman-Monteith method}

The FAO Penman-Monteith equation which is used in the present study is one of the standard methods of estimation of $\mathrm{ET}_{0}$. It is a close, simple representation of the physical and physiological factors governing the evapotranspiration process. In Penman-Monteith method, there are 19 different sub-steps included in the calculation of different parameters in the Penman-Monteith equation (Zotarelliet al.,2015). The equation is;

$$
\mathrm{ET}_{0}=\frac{0.408 \Delta\left(\mathrm{R}_{\mathrm{N}}-\mathrm{G}\right)+\gamma \frac{900}{\mathrm{~T}+27 \mathrm{~g}} \mathrm{u}_{2}\left(\mathrm{e}_{\mathrm{g}}-\mathrm{e}_{\mathrm{g}}\right)}{\Delta+\gamma\left(1+0.34 \mathrm{u}_{2}\right)}
$$

Where, $\mathrm{ET}_{0}$ is reference evapotranspiration [mmday $\left.{ }^{1}\right] ; \mathrm{R}_{\mathrm{N}}$ is net radiation at the crop surface $\left[\mathrm{MJ} / \mathrm{m}^{2} /\right.$ day]; $\mathrm{G}$ is soil heat flux density $\left[\mathrm{MJm}^{-2} \mathrm{day}^{-1}\right] ; \mathrm{T}$ is mean daily air temperature at $2 \mathrm{~m}$ height $\left[{ }^{\circ} \mathrm{C}\right] ; \mathrm{u}_{2}$ is wind speed at $2 \mathrm{~m}$ height $\left[\mathrm{ms}^{-1}\right] ; \mathrm{e}_{\mathrm{s}}$ is saturation vapour pressure $[\mathrm{kPa}] ; \mathrm{e}_{\mathrm{a}}$ is actual vapour pressure $[\mathrm{kPa}] ; \mathrm{e}_{\mathrm{s}}-\mathrm{e}_{\mathrm{a}}$ is saturation vapour pressure deficit $[\mathrm{kPa}] ; \Delta$ is slope vapour pressure curve $\left[\mathrm{kPa} /{ }^{\circ} \mathrm{C}\right]$ and $\gamma$ is psychrometric constant $\left[\mathrm{kPa} /{ }^{\circ} \mathrm{C}\right]$.

Spatial distribution maps of $\mathrm{ET}_{0}$ calculated using the FAO Penman-Monteith equation is used for generating spatial distribution maps of the $\mathrm{ET}_{\mathrm{a}}$ based on the relationship between $\mathrm{K}_{\mathrm{C}}$ and $\mathrm{ET}_{0}$, i.e. $\mathrm{K}_{\mathrm{C}}=\mathrm{ET}_{\mathrm{a}} / \mathrm{ET}_{0}$.

\section{SWAT Hydrological model}

SWAT is a basin-scale, continuous time, hydrologic distributed model that uses spatially distributed data on soil, land use, DEM, and weather data for hydrologic modeling and operates on a daily time step (Narasimhan and Srinivasan, 2001). SWAT is able to predict the impact of land management practices on soil, waterand crop growth. The main output components of the SWAT model consist of weather, hydrology, plant growth, nutrient, pesticide, bacteria and land management (Arnold et al., 1994).

For understanding and spatially explicit parameterization, watershed was delineated into 37 subbasins based on topography using an SRTM DEM. The DEM based stream definition is carried out in the watershed delineation. The area of the watershed is approximately 

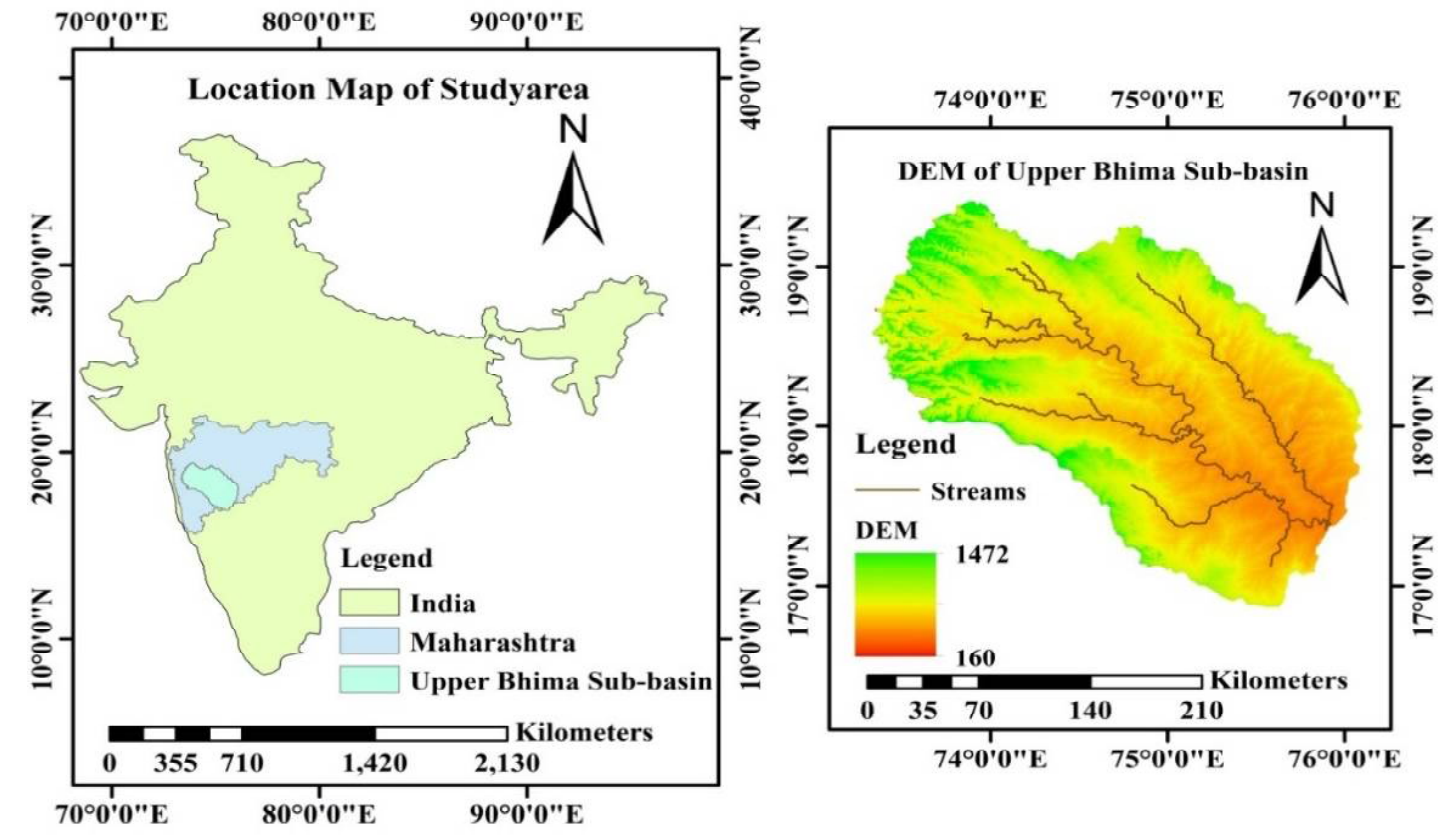

Fig.1: Location map and DEM of the Upper Bhima sub-basin

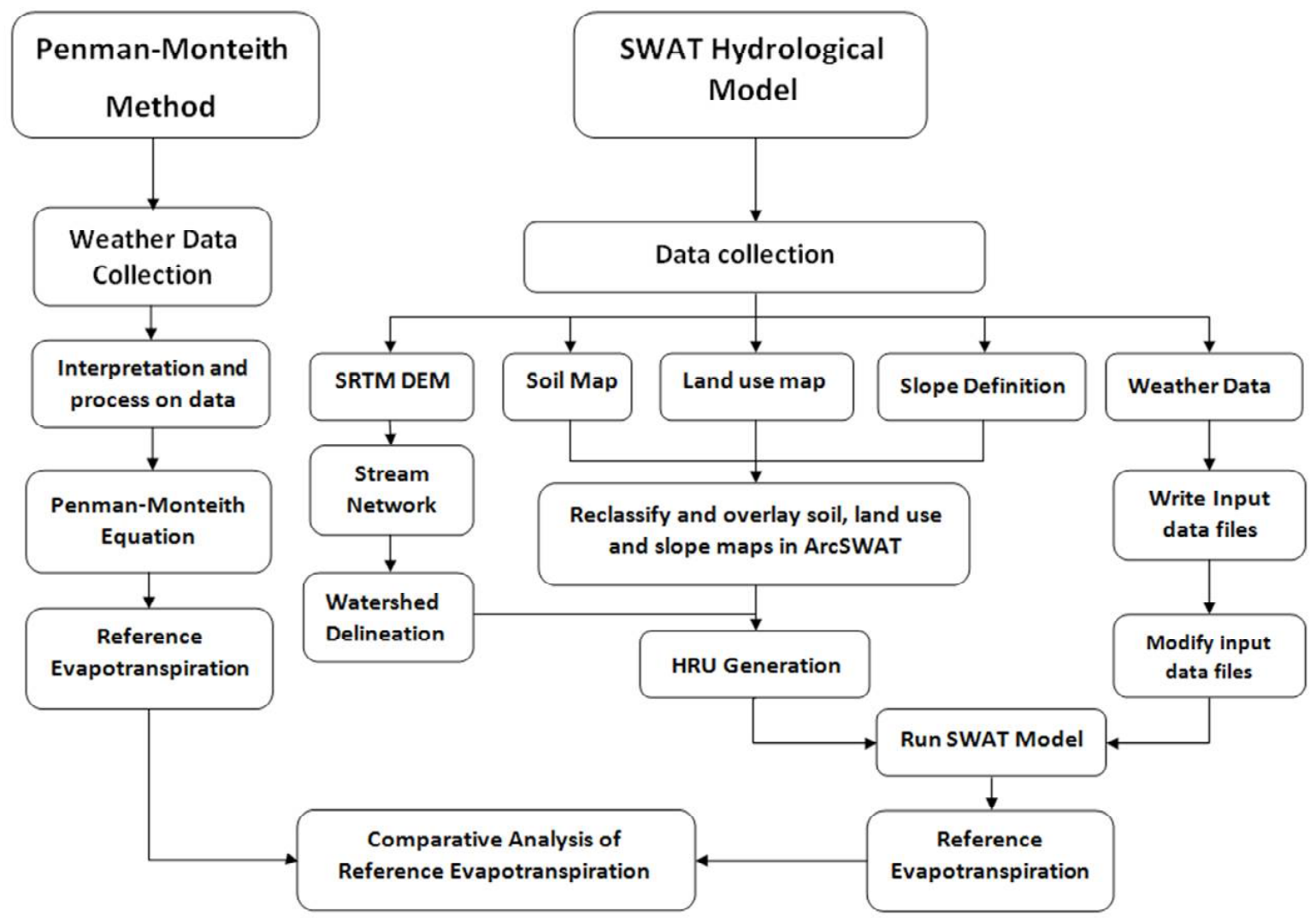

Fig.2:Overall methodology adopted for the analysis

$46,066 \mathrm{~km}^{2}$. The delineated watershed is further subdivided into Hydrological Response Units (HRUs) based on unique soil, land use and slope characteristics combinations. SWAT computes evaporation from soils and plants separately.
The water balance is calculated using the following Eq.

$$
\mathrm{SW}_{\mathrm{t}}=\mathrm{SW}_{0}+\sum_{\mathrm{i}=1}^{\mathrm{t}}\left(\mathrm{R}_{\text {day }}-\mathrm{Q}_{\text {Surf }}-\mathrm{ET}_{\mathrm{a}}-\mathrm{W}_{\text {seep }}-\mathrm{Q}_{\mathrm{gw}}\right)
$$

Where, $\mathrm{SW}_{\mathrm{t}}$ is the soil water content; $\mathrm{SW}_{0}$ is the initial 
soil water content; $\mathrm{R}_{\text {day }}$ is the amount of precipitation; $\mathrm{Q}_{\text {surf }}$ is the surface runoff; $\mathrm{ET}_{\mathrm{a}}$ is the evapotranspiration; $\mathrm{W}_{\text {seep }}$ is the soil infiltration and $\mathrm{Q}_{\mathrm{gw}}$ is the return flow.

\section{Spatial interpolation and map algebra}

Inverse Distance Weighted (IDW) method which works best for dense, evenly-spaced sample points is used for spatial interpolation of $\mathrm{ET}_{0}$ using data at 38 weather stations in the study area. $\mathrm{K}_{\mathrm{C}}$ maps were generated by using the NDVI maps. NDVI based $\mathrm{K}_{\mathrm{C}}$ is one of the best suitable method since there is a linear relation between NDVI and $\mathrm{K}_{\mathrm{C}}$ (Kamble et al., 2013; Chengote and Katpatal, 2016). The difficulty of collecting $\mathrm{K}_{\mathrm{C}}$ data from the field is overcome by using this method. The $\mathrm{K}_{\mathrm{C}}$ varies in space and time, land use pattern, type and stages of crops, precipitation variation, emissivity, vegetation amount and atmospheric boundary conditions, such as air temperature, wind speed and vapour pressure deficit. The linear relation between NDVI and $\mathrm{K}_{\mathrm{C}}$ was given by Kamble et al. (2013) as equation

$$
\mathrm{K}_{\mathrm{CNDVI}}=1.457 \mathrm{NDVI}-0.1725
$$

Where, $\mathrm{K}_{\text {CNDVI }}$ is the NDVI based $\mathrm{K}_{\mathrm{C}}$; NDVI is Normalized Difference Vegetation Index $(-1$ to +1$)$. This equation is carried out by the tool Map Algebra in ArcGIS for the generation of $\mathrm{K}_{\mathrm{C}}$.

\section{RESULTS AND DISCUSSION}

The study is carried for the period from 2000 to 2013. The results discussed in this section are for the representative months and years only. The results obtained from two different methods i.e. the Penman-Monteith method and simulation of the SWAT hydrological model are compared for various ENSO events, i.e. El Niño, La Niña and Normal years.

\section{Monthly variation of actual evapotranspiration for El Niño, La Niña and normal years}

The SWAT model was simulated from 1996 to 2013 including first 3 years as warming up period for the model. As ET $\mathrm{a}_{\mathrm{a}}$ is the parameter which strongly depends on the weather parameters, it is important to discuss variation of $\mathrm{ET}_{\mathrm{a}}$. This variation gives information about the rate of $\mathrm{ET}_{\mathrm{a}}$ during the El Niño, La Niña and normal years. Since El Niño is a warm phase of the ENSO event, the values of $\mathrm{ET}_{\mathrm{a}}$ in June 2003 and June 2009 is $59.473 \mathrm{~mm}$ and $41.7989 \mathrm{~mm}$, respectively which is much more than the La Niña years; $22.127 \mathrm{~mm}$ inJune 2007 and $30.753 \mathrm{~mm}$ in June 2011. Fornormal years (June 2005 and 2012),ET values are32.95 $\mathrm{mm}$ and $22.930 \mathrm{~mm}$, respectively (Fig.4). In general, from the results of the estimated monthly $\mathrm{ET}_{\mathrm{a}}$ shown in Fig.4, it is observed that the monthly ET increases from relatively low values (June to September) to high values (February to May).

Comparing $\mathrm{ET}_{0}$ and $\mathrm{ET}_{\mathrm{a}}$ in the El Niño, La Niña and Normal years, it is observed that the annual average values of $\mathrm{ET}_{0}$ and ET a during El Niño years is maximum, moderate in normal year and minimum in La Niña year as shown in Fig.3. Statistical analysis of ET ${ }_{a}$ calculated by PenmanMonteith method and SWAT model is carried out to compare the results from both the methods. SWAT model also utilizes PM method but generates only one value of result for whole area under consideration while FAO PM Equation has been used to generate result for each weather station in the study area which highlights the spatial variation. Spearman's rho and Kendall's Tau_b methods have been used for correlation. The correlation coefficients are shown in Table 1. It may be observed that correlation is maximum for normal years and minimum for La Niña years whereas it is moderate for El Niño years. Spearman's rho coefficientfor El Niño years is 0.825 , is 0.663 for La Niña years and is 0.867 for normal years. Whereas,Kendall's Tau_b coefficient is same for El Niño and Normal years ( 0.667$)$; and is 0.560 for La Niña years. In the month of June and July, the rate of $\mathrm{ET}_{\mathrm{a}}$ variation depends on the starting of the monsoon rainfall. Generally, the monsoon period starts in the month of June, but because of climate change events such as ENSO, it alters the starting date of the rainfall and its intensity during monsoon. As the ENSO affects the temperature and rainfall, it also affects the rate of $\mathrm{ET}_{\mathrm{a}}$.

\section{Spatial distribution of ET,}

$\mathrm{ET}_{0}$ values calculated for 38 weather stations in the study area by using the Penman-Monteith equationwere interpolatedusing the IDW method. Spatial distribution of $\mathrm{ET}_{0}$ indicates its variation throughout the sub-basin. $\mathrm{As}_{\mathrm{ET}}$ maps are generated by using $\mathrm{ET}_{0}$ maps, it is important to

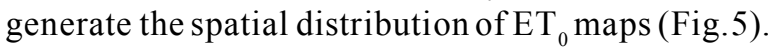

\section{Spatial distribution of NDVI based crop coefficient (K)}

MODIS NDVI data are collected for the period from year 2000 to 2013. The impact of warm and cold phases of ENSO (El Niño and La Niña) can be distinguished from the vegetation patterns over India if the consequent years of warm and cold phases are considered (Kumar et al., 2013).Variation in the NDVI values hence is based on temperature, precipitation, available moisture, type of the crop or vegetation and growing stage of the vegetation (Rishma and Katpatal, 2016). The change in NDVI would certainly affect the $\mathrm{ET}_{\mathrm{a}}$ which is estimated using $\mathrm{K}_{\mathrm{C}}$. It can be easily observed that the $\mathrm{K}_{\mathrm{C}}$ is higher in September and 
(ET0)

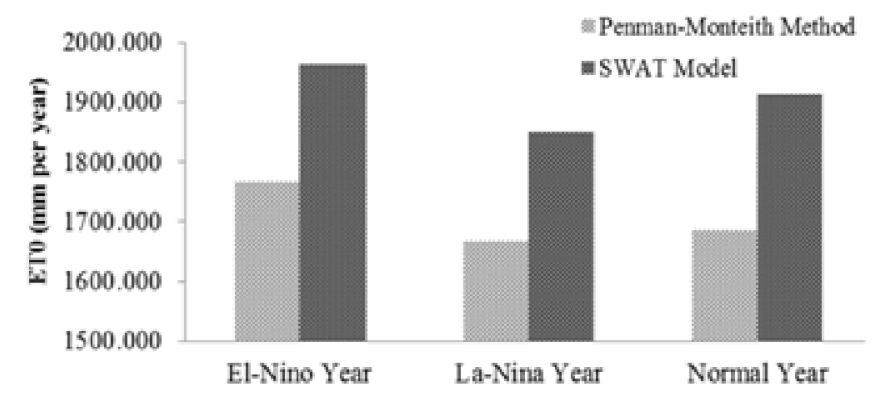

(ETa)

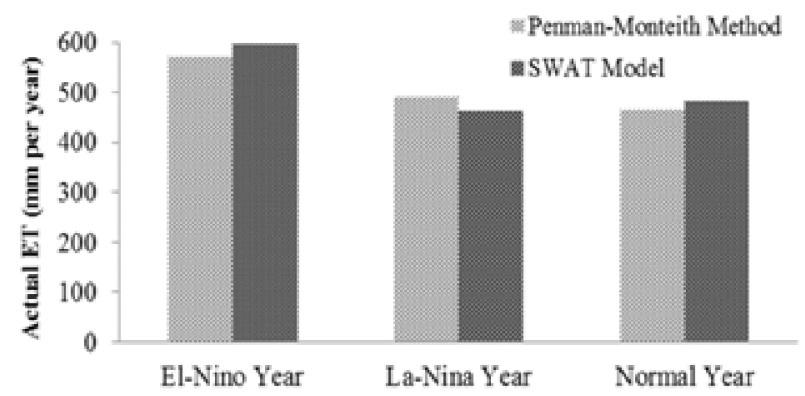

Fig.3: Annual average $\mathrm{ET}_{0}$ and $\mathrm{ET}_{\mathrm{a}}$ variation during the El Niño, La Niña and Normal years

\section{EI-Nino Years}
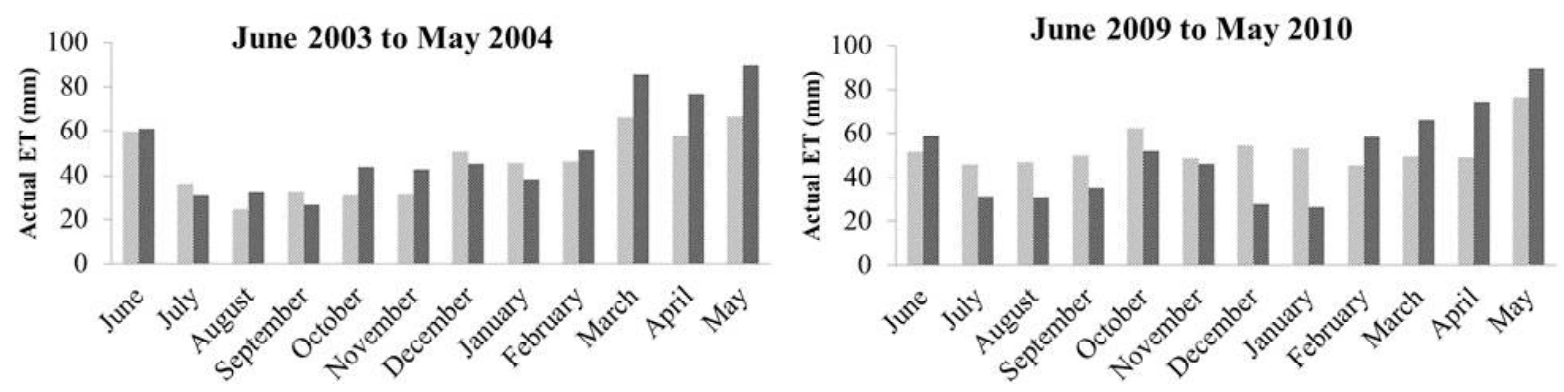

\section{La-Nina Years}
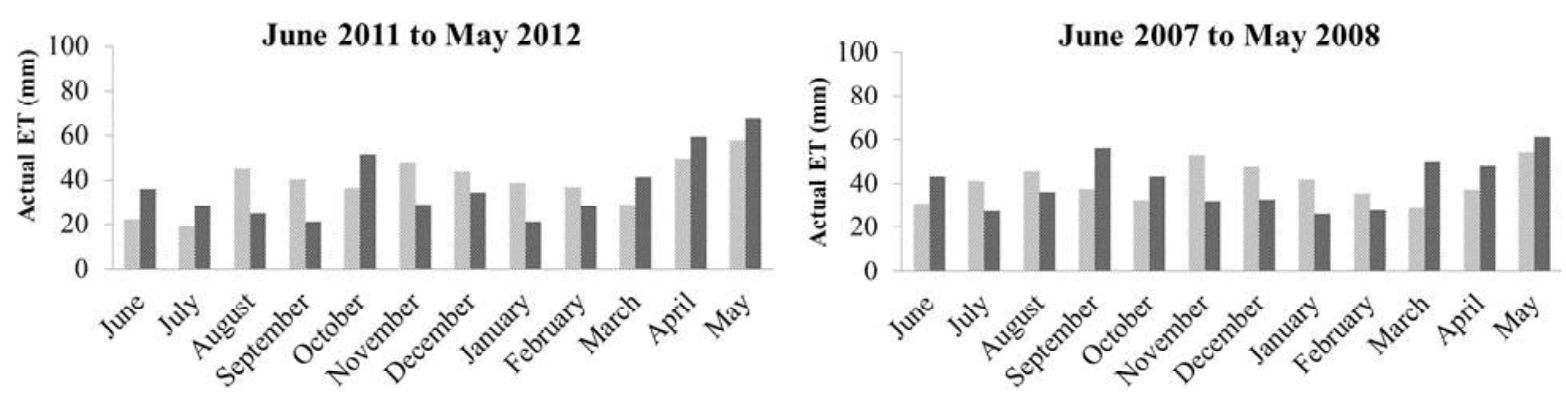

\section{Normal Years}

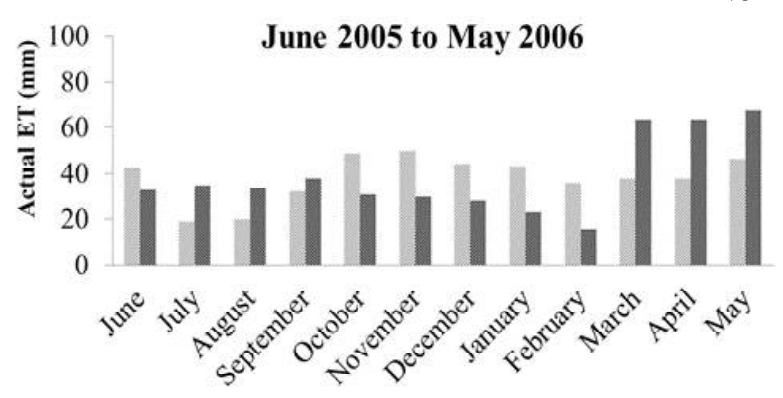

Penman-Monteith method

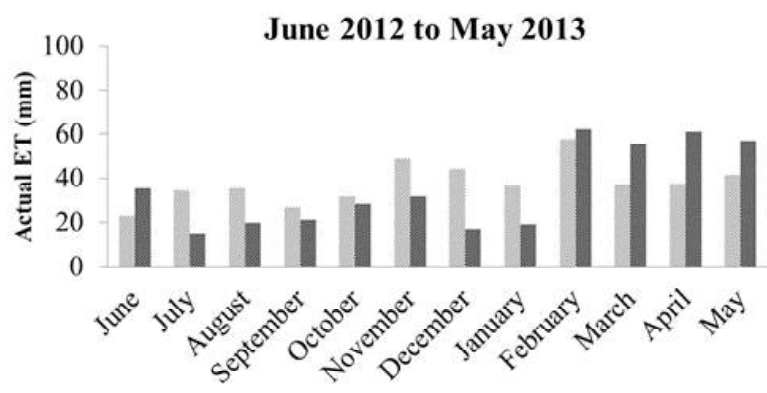

SWAT model

Fig.4: Monthly variation ofET for El Niño, La Niña and Normal years

December than in February, May and July. After the monsoon period, there is an increase in the growth of the crops which results in the more $\mathrm{K}_{\mathrm{C}}$ values. $\mathrm{K}_{\mathrm{C}}$ maps of pre-monsoon, monsoon and post-monsoon period for the 2001, 2002, 2007 and 2013 are shown in Fig. 6.

\section{Spatial distribution of Actual ET}

The spatial distribution maps of May month show the maximum $\mathrm{ET}_{\mathrm{a}}$; these are nothing but the ET from the water bodies' i.e. Bhima river in the sub-basin. This value ranges from $5.20 \mathrm{~mm} /$ day to $8.60 \mathrm{~mm} /$ day. Annual average of $\mathrm{ET}_{\mathrm{a}}$ 


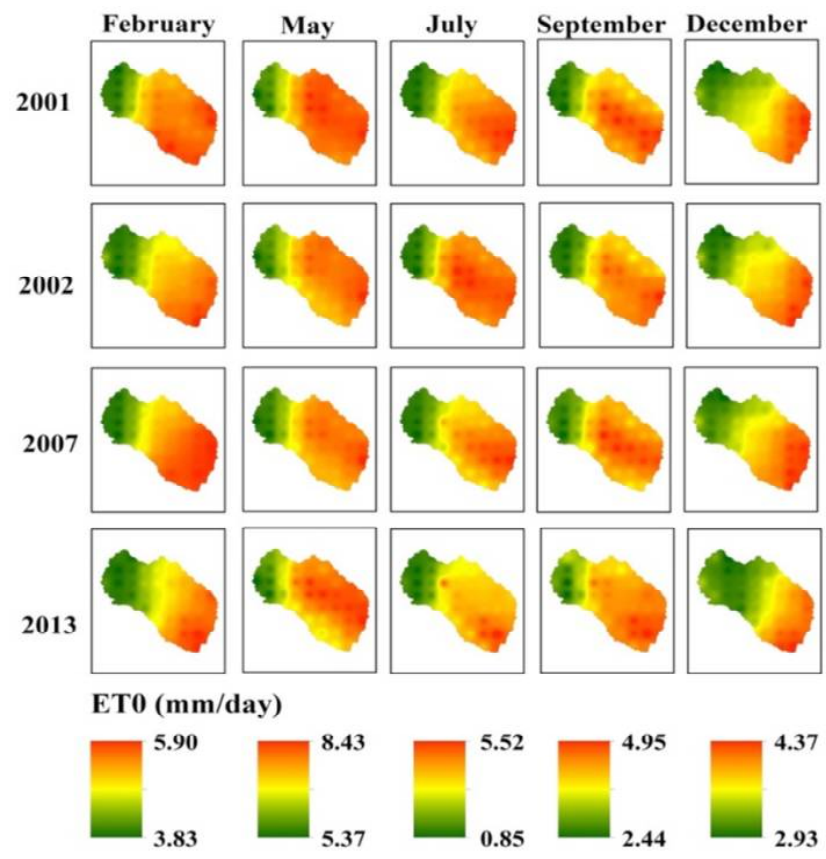

Fig.5: Spatial distribution of $\mathrm{ET}_{0}$

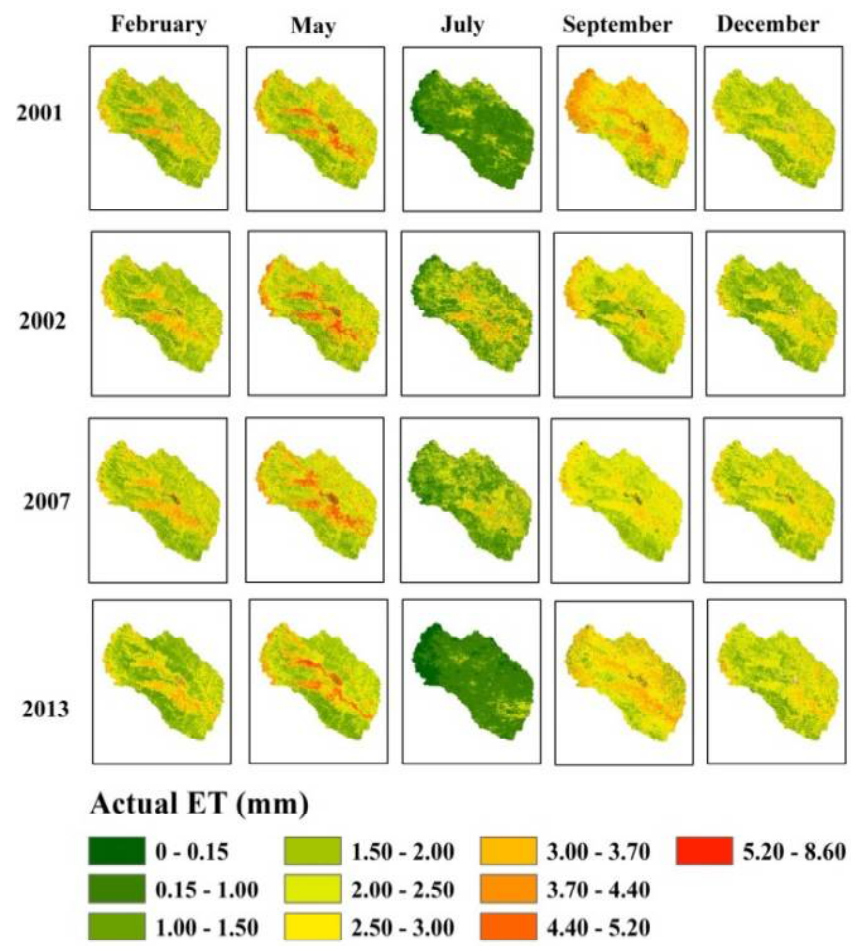

Fig.7: Spatial distribution of actual ET

during Julyis minimum. Almost the whole study area shows minimum value ranging from 0 to $1 \mathrm{~mm} /$ day of $\mathrm{ET}_{\mathrm{a}}$ (Fig.7). The maximum and minimum $\mathrm{ET}_{\mathrm{a}}$ is seen in the month May and July respectively which can be validated in Fig.7.Comparing the $\mathrm{ET}_{0}$ in the different ENSO years, normal year shows the minimum ET as compared to El Niño and La Niña year. In 2002, an El Niño year shows the maximum ET than La Niña and normal year. The year 2013 was the major drought year

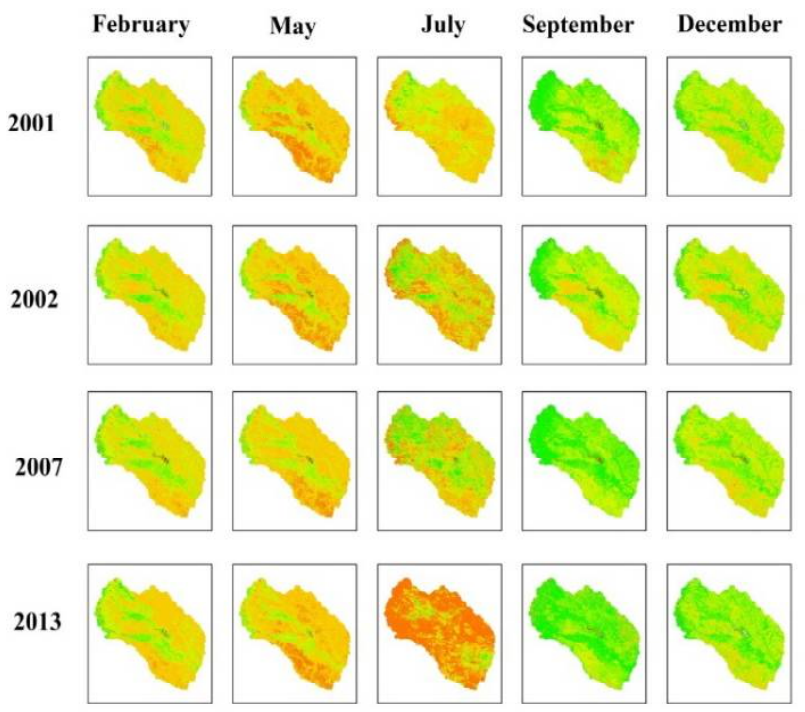

Crop Coefficient

\begin{tabular}{|l|l|l|l|l|l|}
\hline$<0$ & $0-0.2$ & $0.2-0.4$ & $0.4-0.6$ & $0.6-0.8$ & 0.8 - 1 \\
\hline
\end{tabular}

Fig.6: Spatial distribution of crop coefficient

Table1: Summary of statistical analysis between ET $\mathrm{a}_{\mathrm{a}}$ by Penman-Monteith Method and SWAT Model

\begin{tabular}{lll}
\hline & Spearman's rho & Kendall's Tau_b \\
\hline E1 Niño Years & 0.825 & 0.667 \\
La NiñaYears & 0.663 & 0.560 \\
NormalYears & 0.867 & 0.667 \\
\hline
\end{tabular}

in Maharashtra because of the lowest rainfall in 2012. Due to this, as the available moisture was very less in 2013, the $\mathrm{ET}_{\mathrm{a}}$ is also less as compared to other years.

\section{CONCLUSION}

In this study, $\mathrm{ET}_{0}$ estimated using FAO PenmanMonteith method and SWAT model have been analyzed for the period from 2000 to 2013 to evaluate the impact of various ENSO phases on changes in $\mathrm{ET}_{0}$ patterns across Upper Bhima Sub-Basin. Comparisons between ET from Penman-Monteith method and SWAT model indicate the annual magnitude and general outlines in $\mathrm{ET}_{\mathrm{a}}$ across the study area. The temporal analysis of monthly $\mathrm{ET}_{\mathrm{a}}^{\mathrm{a}}$ shows that the summer period from February to May contributes up to $65 \%$ of annual $\mathrm{ET}_{\mathrm{a}}$, of which ET $\mathrm{in}$ May accounts for $25 \%$. Results suggest that the El Niño yearshave a greater influence on the $\mathrm{ET}_{0}$ and $\mathrm{ET}_{\mathrm{a}}$ change patternsas compared to those of La Niña and normal years. The spatial distribution of ET, estimated from NDVI based $\mathrm{K}_{\mathrm{C}}$ and $\mathrm{ET}_{0}$ gives the actual status of evapotranspiration in the Upper Bhima sub-basin.

This study proposes an appropriate approach for the estimation of $\mathrm{ET}_{\mathrm{a}}$ and assesses its spatio-temporal variations 
at the watershed scale with high spatio-temporal resolution. The analysis of the $\mathrm{ET}_{\mathrm{a}}$ for ENSO events such as El Niño, La Niña and normal years provides important knowledge to study its variation at watershed scale. Future research may include the correlation of the different meteorological parameters affecting on the $\mathrm{ET}_{\mathrm{a}}$ and its spatio-temporal variations according to the various agroclimatic zones within the study area.

\section{REFERENCES}

Abiodun, O.O., Guan, H., Post, V.E.A. andBatelaan, O. (2018).Comparison of MODIS and SWAT evapotranspiration over a complex terrain at diûerent spatial scales.Hydrol. Earth Syst. Sci., 22(5): 27752794.

Arnold, J.G., Williams, J.R., Srinivasan, R., King, K.W. and Griggs, R.H.(1994). SWAT: Soil and Water Assessment Tool. USDAAgricultural Research Service, Temple, TX.

Chengote, R. and Katpatal, Y.B. (2016).Footprints of El Niño Southern Oscillation on Rainfall and NDVI-Based Vegetation Parameters in River Basin in Central India.J. Hydrol. Eng., 21(12): 05016030.

CWC and NRSC. (2014). Report on Krishna Basin by Central Water Commission \&National Remote Sensing Centre.http://india-wris.nrsc.gov.in/ Publications/ BasinReports/Krishna 20 Basin.pdf

DRAFT report, Upper Bhima Sub basin, K-5 Bhima Sub Basin.http://www.india-wris.nrsc.gov.in/Publications/ BasinReports/Krishna20Basin.pdf.

Garg, K.K., Bharati, L., Gaur, A., George, B., Acharya, S., Jella, K.and Narasimhan,B. (2012). Spatial mapping of agricultural water productivity using the SWAT model in Upper Bhima Catchment, India.Irrig.Drain., 61(1):6079.

Hamon, W.R.(1961). Estimating potential evapotranspiration. $J$. Hydraul. Eng., 87(3):107-120.

Hargreaves, G.H., and Allen, R.G. (2003).History and evaluation of Hargreaves evapotranspiration equation.J.Irrig. Drain. Eng., 129(1): 53-63.

Kamble, B. and Kilic, A. and Hubbard, K. (2013).Estimating Crop Coefficients Using Remote Sensing-Based Vegetation Index.Remote Sens., 5(4): 1588-1602.

Kumar, T.,Koteswara Rao, K.,Humberto,B. andEmily,P.J. (2013).Studies on spatial pattern of NDVI over India and its relationship with rainfall, air temperature, soil moisture adequacy and ENSO.Geofizika, 30:1-18.
Mann, H.B. (1945). Nonparametric tests against trend. Econometrica, 245-259.

Monteith, J.L. (1965). Evaporation and the environment. In: The State and Movement of Water in Living Organisms, pp. 205-234. XIXth Symposium of the Society for Experimental Biology, Swansea. Cambridge, UK: Cambridge University Press.

Narasimhan, B. and Srinivasan, R. (2001). Development of a soil moisture index for agricultural drought monitoring using hydrologic model(SWAT), GIS and Remote Sensing.The 2002 Texas Water Monitoring Congress Proceedings, The Univ. of Texas at Austin, September 9-11, 2002.

Penman, H.L. (1948).Natural evaporation from open water, bare soil and grass. In: Proceedings of the Royal Society of London. Series A: Mathematical and Physical Sciences, 193: $120-146$.

Reynolds, C.A., Jackson, T.J. and Rawls W.J.(1999). Estimating available water content by linking the FAO soil map of the world with global soil profile database and pedotransfer functions. In: Proc. AGU 1999 Spring Conf., Boston, MA.

Rishma C. and KatpatalY.B. (2016). Variability in Rainfall and Vegetation density as a Response to ENSO Events: A Case Study in Venna River Basin of Central India, $J$. Agrometeorol., 18 (2): 300-305.

Schuol, J. and Abbaspour,K.(2007). Using monthly weather statistics to generate daily data in a SWAT model application to West Africa. Ecol. Model., 201(3-4):301311.

Shrestha, L. and Shrestha, N.K. (2017). Assessment of climate change impact on crop yield and irrigation water requirement of two major cereal crops (rice and wheat) in Bhaktapur district, Nepal.J. Water Clim. Change,8(2): 320-335.

Spearman, C.(1904).The Proofand Measurement of Association between Two Things.Am. J. Psychol. 15: 72-101.

Thornthwaite, C.W. and Mather, J.R. (1957). Instructions and tables for computing potential evapotranspiration and the water balance. Publications in Climatology, Volume X, No. 3, Centerton, New Jersey, 185pp.

Lincoln,Z.,Michael,D.D.,Consuelo,C.R.,Kati,W.M. and Kelly,T.M. (2015). Step by Step Calculation of the Penman-Monteith Evapotranspiration (FAO-56 Method).AE459, University of Florida.1-10. 